\title{
Pattern of primary caesarean deliveries in a Nigerian tertiary hospital
}

\author{
Abimbola T. Ottun ${ }^{1 *}$, Chinonye H. Okoye ${ }^{2}$, Adeniyi A. Adewunmi ${ }^{1}$, \\ Faosat O. Jinadu ${ }^{3}$, Ayokunle M. Olumodeji ${ }^{2}$
}

\begin{abstract}
${ }^{1}$ Department of Obstetrics and Gynaecology, Lagos State University College of Medicine/Lagos State University Teaching Hospital, Ikeja, Lagos, Nigeria

${ }^{2}$ Department of Obstetrics and Gynaecology, Lagos State University Teaching Hospital, Ikeja, Lagos, Nigeria

${ }^{3}$ Department of Radiology, Lagos State University College of Medicine/Lagos State University Teaching Hospital, Lagos, Ikeja, Nigeria
\end{abstract}

Received: 21 March 2021

Accepted: 29 April 2021

\section{*Correspondence:}

Dr. Abimbola T. Ottun,

E-mail: taottun@yahoo.com

Copyright: ( ) the author(s), publisher and licensee Medip Academy. This is an open-access article distributed under the terms of the Creative Commons Attribution Non-Commercial License, which permits unrestricted non-commercial use, distribution, and reproduction in any medium, provided the original work is properly cited.

\section{ABSTRACT}

Background: Primary caesarean section (CS) has become a major driver of the steadily rising total caesarean rate. This study determined the primary CS rate, pattern and associated factors.

Methods: It was a retrospective, hospital-based cross-sectional study of 645 pregnant women who had primary caesarean section over a 3-year period in Lagos state university teaching hospital, Lagos, Nigeria. Data obtained were expressed in frequency and percentages.

Results: Primary CS accounted for more than $50 \%$ of all the CS done during the study period with a primary CS rate of $16.7 \%$ and total CS rate was $30.6 \%$. Primary CS was commonest among women of age group 30-39years (50.1\%) and women with no prior parous experience $(58.6 \%)$. The commonest indication for primary CS was poor progress in labour due to cephalopelvic disproportion, which occurred in 170 women $(26.4 \%)$, followed by suspected foetal distress in 94 women $(14.6 \%)$ and hypertensive disease in pregnancy in 91 women $(14.1 \%)$. Post-operative wound infection and/or dehiscence was the most prevalent post-operative complication occurring in $12.1 \%$ of women who had primary CS.

Conclusions: Primary CS rate is increasing and relatively more common among primiparous women. Cephalopelvic disproportion, suspected foetal distress and hypertensive disorders of pregnancy are the leading indications for primary CS.

Keywords: Primary caesarean section, Caesarean section, Caesarean delivery

\section{INTRODUCTION}

Caesarean section (CS) is a life-saving obstetric surgery, which may be necessitated in high-risk pregnancies. ${ }^{1}$ It is recommended in situations in which vaginal birth presents a greater likelihood of adverse maternal or perinatal outcomes than normal. ${ }^{2}$ However, caesarean section is associated with a higher risk of complications, especially when performed without a clear medical indication. ${ }^{2}$ One of the most dramatic features of modern obstetrics is the relentless increase in caesarean section rate which is a major public health concern globally. ${ }^{3}$ The global rate of CS delivery is rising steadily and has reached a rate of $21.1 \%$ of all births in 2015 with an average annual increasing rate of $3.7 \%$ during 20002015. ${ }^{4}$

The world health organization (WHO) recommends an upper limit CS rate of $15 \%$ of all deliveries. ${ }^{5}$ The rising rate of $\mathrm{CS}$ indicates that this life saving intervention is being practiced higher than the expected level on the basis of obstetric indications in many countries. ${ }^{4} \mathrm{CS}$ can also be costly and places poor families under extreme financial pressure in low- and middle-income countries 
(LMIC) and thus bring negative, economic and health related repercussion. ${ }^{3,5}$

Primary CS is CS done for the first time in a pregnant woman and it has become a major driver of the total caesarean rate. ${ }^{7,8}$ Understanding the population trends in primary caesarean section rates and potential drivers of these trends will provide important insights to target areas for reducing overall caesarean section rate. ${ }^{8,9}$ This study aimed to determine the primary CS rate, pattern and associated factors in Lagos State University Teaching Hospital, Lagos, Nigeria.

\section{METHODS}

This was a retrospective, cross-sectional study in which data from medical records of 645 women who had primary CS between $1^{\text {st }}$ of January 2015 and $31^{\text {st }}$ of December 2017 were retrieved. Records of pregnant women who had abdominal surgical delivery of their babies at gestational age of less than 28 weeks were not included.

Data were obtained by the researchers from the antenatal, labour ward and theatre registers of the Lagos State University teaching hospital using a structured proforma designed for the study. The proforma included information on socio-demography, booking status, past obstetric history, antenatal history, record of events of labour, type of caesarean delivery (emergency or elective), gestational age at delivery and post-delivery feto-maternal outcomes.
Data analysis was done using SPSS version 23 (IBM). Categorical variables were presented in frequency and percentages. Confidentiality of retrieved data was ensured and ethical approval was not deemed mandatory

by the institutional ethical review board because the study was essentially a retrospective review of existing medical records.

\section{RESULTS}

Six hundred and forty-five (80\%) of women with complete data who had primary CS during the study period had their data analysed (Figure 1). Primary CS accounted for more than $50 \%$ of all the CS done per year during the study period and a primary CS rate of $16.7 \%$ over the study period (Table 1). Total CS rate was $30.6 \%$ (Table 1).

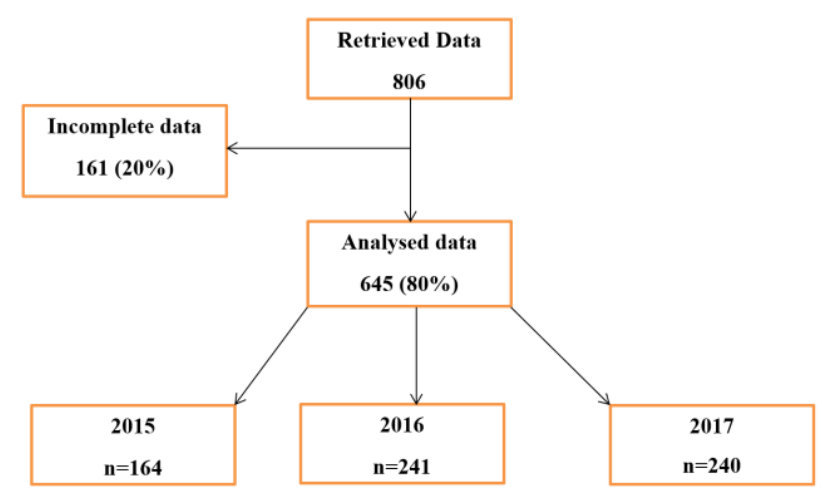

Figure 1: Flow chart of study data.

Table 1: Distribution of primary caesarean section by year and type.

\begin{tabular}{|lllllll|} 
Year & $\begin{array}{l}\text { Total no. of } \\
\text { deliveries }\end{array}$ & $\begin{array}{l}\text { Total CS } \\
\text { n, (CS rate, } \%)\end{array}$ & $\begin{array}{l}\text { Primary CS } \\
\text { n, (\% of total CS) }\end{array}$ & $\begin{array}{l}\text { Primary CS } \\
\text { (\% of primary CS) }\end{array}$ & \multicolumn{2}{c|}{$\begin{array}{l}\text { Primary CS } \\
\text { rate, }(\%)\end{array}$} \\
\hline $\mathbf{2 0 1 5}$ & 1013 & $302(29.8)$ & $164(54.3)$ & $42(25.6)$ & $122(74.4)$ & 16.2 \\
\hline $\mathbf{2 0 1 6}$ & 1327 & $421(31.7)$ & $241(57.3)$ & $66(27.4)$ & $175(72.6)$ & 18.2 \\
\hline $\mathbf{2 0 1 7}$ & 1524 & $461(30.2)$ & $240(52.1)$ & $62(25.8)$ & $178(74.2)$ & 15.7 \\
\hline Total & 3864 & $1184(30.6)$ & $645(16.7)$ & $170(26.4)$ & $475(73.6)$ & 16.7 \\
\hline
\end{tabular}

CS-Caesarean section, Total CS=Primary CS and repeat CS.

Primary CS was commonest among women of age group $30-39 y e a r s(50.1 \%)$ and women with no prior parous experience $(58.6 \%)$ (Table 2$)$. The commonest indication for primary CS was poor progress in labour, which occurred in 170 women $(26.4 \%)$, followed by suspected foetal distress in 94 women (14.6\%) and hypertensive disease in pregnancy in 91 women $(14.1 \%$ ) (Table 3$)$.

Of the leading indications for primary CS, majority of the women $(89.4 \%)$ who had poor progress of labour developed it in the first stage of labour. In women who had primary CS on account of the suspected foetal distress, intermittent auscultation of foetal heart rate $(51.7 \%)$ was more commonly used than continuous electronic foetal heart rate monitoring $(48.3 \%)$ to make a diagnosis of suspected foetal distress (Table 4). Severe pre-eclampsia/eclampsia accounted for $80.2 \%$ of indications for primary CS due to hypertensive disorders of pregnancy as shown in the Table 4.

Only $2.6 \%$ of women (17) who had primary CS remained on admission till post-operative day 10, perinatal mortality was $1.9 \%$ and maternal mortality was $0.6 \%$ (Table 5). Commonest complication observed in women who had primary CS was wound infection/dehiscence which occurred in $12.1 \%$ of the study population (Table $6)$. 
Table 2: Socio-demographic characteristics of women who had primary caesarean section $(n=645)$.

\begin{tabular}{|c|c|c|}
\hline Variables & $\mathbf{N}$ & $\%$ \\
\hline \multicolumn{3}{|c|}{ Age group, (years) } \\
\hline$<20$ & 10 & 1.6 \\
\hline $20-29$ & 267 & 41.3 \\
\hline $30-39$ & 323 & 50.1 \\
\hline$\geq 40$ & 45 & 7.0 \\
\hline \multicolumn{3}{|l|}{$\overline{\text { Parity }}$} \\
\hline 0 & 378 & 58.6 \\
\hline 1 & 115 & 17.8 \\
\hline $2-5$ & 145 & 22.5 \\
\hline$>5$ & 7 & 1.1 \\
\hline \multicolumn{3}{|l|}{ Ethnic group } \\
\hline Yoruba & 292 & 45.3 \\
\hline Igbo & 284 & 44.0 \\
\hline Hausa & 18 & 2.8 \\
\hline Others & 51 & 7.9 \\
\hline \multicolumn{3}{|l|}{ Religion } \\
\hline Christianity & 410 & 63.6 \\
\hline Islam & 201 & 31.3 \\
\hline Traditional & 34 & 5.3 \\
\hline \multicolumn{3}{|l|}{ Marital status } \\
\hline Married & 639 & 99.1 \\
\hline Single & 6 & 0.9 \\
\hline \multicolumn{3}{|l|}{ Occupation } \\
\hline Housewives & 130 & 20.2 \\
\hline Civil servants & 80 & 12.4 \\
\hline Professionals & 116 & 18.0 \\
\hline Traders & 264 & 41.0 \\
\hline Applicants & 10 & 1.54 \\
\hline Students & 32 & 5.0 \\
\hline Others & 11 & 1.7 \\
\hline \multicolumn{3}{|c|}{ Booking status } \\
\hline Booked & 574 & 89.0 \\
\hline Un-booked & 71 & 11.0 \\
\hline
\end{tabular}

Table 3: Indications for primary caesarean section $(n=645)$.

\begin{tabular}{|lll|}
\hline Indications & $\mathbf{N}$ & $\%$ \\
\hline Poor progress in labour & 170 & 26.4 \\
\hline Cephalopelvic disproportion & 150 & 23.3 \\
\hline Obstructed labour & 20 & 3.1 \\
\hline Failed induction & 32 & 5.0 \\
\hline Foetal distress & 94 & 14.6 \\
\hline Abnormal presentation & 63 & 9.8 \\
\hline $\begin{array}{l}\text { Hypertensive disease in } \\
\text { pregnancy }\end{array}$ & 91 & 14.1 \\
\hline Foetal anomalies & 6 & 0.9 \\
\hline Multiple gestation & 19 & 2.9 \\
\hline Previous uterine scar & 3 & 0.5 \\
\hline PMTCT & 14 & 2.2 \\
\hline Suspected foetal macrosomia & 38 & 5.9 \\
\hline Obstetrics factor & 57 & 8.8 \\
\hline Elective & 42 & 6.5 \\
\hline Others & 16 & 2.5 \\
\hline PMTCT-Previon & & \\
\hline
\end{tabular}

PMTCT-Prevention of mother to child transmission of HIV
Table 4: Common indications of primary CS in the study.

\begin{tabular}{|c|c|c|}
\hline Variables & Frequency & $\%$ \\
\hline \multicolumn{3}{|c|}{ Poor progress of labour, $(n=170)$} \\
\hline First stage & 152 & 89.4 \\
\hline Second stage & 18 & 10.6 \\
\hline \multicolumn{3}{|c|}{ Suspected foetal distress by, $(n=94)$} \\
\hline $\begin{array}{l}\text { Intermittent } \\
\text { auscultation }\end{array}$ & 55 & 51.7 \\
\hline Continuous EFM & 39 & 48.3 \\
\hline \multicolumn{3}{|c|}{ Hypertensive disorders, $(n=91)$} \\
\hline $\begin{array}{l}\text { Severe pre- } \\
\text { eclampsia/eclampsia }\end{array}$ & 73 & 80.2 \\
\hline Severe PIH & 18 & 19.8 \\
\hline
\end{tabular}

Table 5: Maternal and foetal outcomes of women who had primary CS.

\begin{tabular}{|c|c|c|}
\hline Variables & Frequency & $\%$ \\
\hline \multicolumn{3}{|c|}{ Perinatal mortality } \\
\hline Yes & 12 & 1.9 \\
\hline No & 633 & 98.1 \\
\hline \multicolumn{3}{|c|}{ Post-operative complications } \\
\hline Yes & 162 & 25.2 \\
\hline No & 482 & 74.8 \\
\hline \multicolumn{3}{|c|}{ Maternal mortality } \\
\hline Yes & 4 & 0.6 \\
\hline No & 641 & 99.4 \\
\hline \multicolumn{3}{|c|}{ Duration of hospital stay (days) } \\
\hline$\leq 5$ & 291 & 45.1 \\
\hline $6-10$ & 337 & 52.3 \\
\hline$>10$ & 17 & 2.6 \\
\hline
\end{tabular}

Table 6: Complications in women who had primary CS.

\begin{tabular}{|lll|}
\hline Complications & Frequency & $\%$ \\
\hline Subtotal hysterectomy & 2 & 0.2 \\
\hline $\begin{array}{l}\text { Postpartum } \\
\text { hemorrhage }\end{array}$ & 8 & 1.3 \\
\hline $\begin{array}{l}\text { Wound sepsis/ } \\
\text { dehiscence }\end{array}$ & 78 & 12.1 \\
\hline UTI & 36 & 5.6 \\
\hline $\begin{array}{l}\text { Cardiac arrest } \\
\text { (resuscitated) }\end{array}$ & 2 & 0.2 \\
\hline $\begin{array}{l}\text { Need for blood } \\
\text { transfusions }\end{array}$ & 33 & 4.1 \\
\hline Maternal death & 4 & 0.6 \\
\hline Total & 163 & 25.3 \\
\hline
\end{tabular}

\section{DISCUSSION}

Primary caesarean section usually determines the future obstetric course of any woman and therefore should be avoided whenever medically possible. The overall caesarean section rate in this study was $30.6 \%$ and a 
primary CS rate of $16.7 \%$. The CS rate found in this study is much higher than $15 \%$, recommended by WHO. ${ }^{10}$ The rate found in this study compares to rates reported in some developed countries such as USA (32.8\%), Rome (44\%) and Australia (31\%). ${ }^{8}$ Local studies in Nigeria have cited caesarean section rate to vary from $10.3 \%$ to $34.5 \%, 18 \%$ reported in Jos, Nigeria $11.8 \%$ reported in Maiduguri, Nigeria, $21 \%$ in Abuja, Nigeria and $19.8 \%$ reported in Calabar, Nigeria. ${ }^{8,9,11,12}$ However, most of these figures are institutional based and may not reflect the true picture in the general population because these centers are referral centers.

As regards parity, we found that $58.5 \%$ of women who had primary CS had no prior parous experience. This is in keeping with findings in other studies that noted CS to be more likely performed in primiparous. ${ }^{9,13,14} \mathrm{We}$ found that poor progress in labour due to cephalopelvic disproportion was the commonest indication for primary CS followed by suspected foetal distress and hypertensive disorders of pregnancy. Daniel et al similarly noted a high rate of poor progress in labour from cephalopelvic disproportion which was particularly prevalent in primiparous women. ${ }^{9}$ Batieha et al in Jordan noted that foetal distress was the commonest indication for emergency CS in their study. ${ }^{13}$ Isah et al in Abuja also noted similar pattern of leading indications for CS, they reported that cephalopelvic disproportion was the most common indication $(30.8 \%)$ followed by foetal distress $(23.6 \%)$ and severe pre-eclampsia/eclampsia $(10.9 \%){ }^{12}$ Ugwu et al in Enugu reported cephalopelvic disproportion and suspected foetal distress as the $2^{\text {nd }}$ and $3^{\text {rd }}$ commonest indications for CS respectively in their study. ${ }^{15}$ This similar pattern of leading indications of CS in Nigeria would therefore suggest that, for significant impact, efforts at reducing caesarean section rates should seek to address the prevention and proper diagnosis and management of poor progress in labour, suspected foetal distress and hypertensive disorders in pregnancy.

We observed that the proportion of women $(51.7 \%)$ who had primary CS on account of suspected foetal distress with the diagnosis made via intermittent auscultation was slightly higher than the proportion of women $(48.3 \%)$ who had similar diagnosis made via continuous external foetal heart rate monitoring using the cardiotocograph machine (Table 4). It thus appears that the diagnosis of suspected foetal distress was more often made by intermittent auscultation. This may imply that, in the absence of resources to perform the definitive foetal scalp sampling for confirmation of foetal distress, prompt sequential reassessment of cases of suspected foetal distress, diagnosed by intermittent auscultation, with a continuous external foetal heart rate monitor may further clarify the diagnosis of foetal distress.

The surgical complication rate in this study was $25.2 \%$ (Table 5). We observed a perinatal loss rate of $1.9 \%$ and maternal mortality rate of $0.6 \%$. Post-operative wound infection and/or dehiscence was the most prevalent post- operative complication occurring in $12.1 \%$ of women who had primary CS. This may be explained by the fact that a large proportion (73.6) of the women studied had emergency CS (Table 1). Panti et al in Sokoto, Chama et al in Maiduguri and Okonta et al in benin reported post CS complication rate of $20.4 \%, 39.3 \%$ and $44.4 \%$ respectively with hemorrhage and sepsis being the leading complications post CS. ${ }^{16-18}$ Our differing postoperative complication pattern may be explained by the limitation of our study to women who had primary CS.

\section{Limitations}

This study could not determine or quantify risk factors for primary CS due to its observational, retrospective and non-comparative nature.

\section{CONCLUSION}

In conclusion, primary $\mathrm{CS}$ rate is relatively more common among primiparous women. Cephalopelvic disproportion, suspected foetal distress and hypertensive disorders of pregnancy are the leading indications for primary CS in Nigeria. Most hospitals in developing countries do not confirm fetal distress in labour due to lack of resources for the confirmation of fetal distress in labour and CS is a usual recourse once fetal distress is suspected. Availability of resources to confirm fetal distress may likely reduce the rate of CS from suspected fetal distress, a leading cause of primary CS identified in this study.

\section{Funding: No funding sources}

Conflict of interest: None declared

Ethical approval: The study was approved by the Institutional Ethics Committee

\section{REFERENCES}

1. WHO. WHO Statement on Caesarean Section Rates. Geneva: World Health Organization. Geneva 2015. Available at https://apps.who.int/iris/bitstream/ handle/10665/161442/WHO_RHR_15.02_eng.pdf?s equence=1. Accessed on 17 March 2021.

2. De Souza HCC, Perdoná GSC, Marcolin AC, Oyeneyin LO, Oladapo OT, Mugerwa K et al. Development of caesarean section prediction models: secondary analysis of a prospective cohort study in two sub-Saharan African countries. Reproductive Health. 2019;16(1):165.

3. Geidam AD, Audu BM, Kawuwa BM, Obed JY. Rising trend and indications of caesarean section at the university of Maiduguri teaching hospital, Nigeria. Ann Afr Med. 2009;8(2):127-32.

4. Boerma T, Ronsmans C, Melesse DY, Barros AJ, Barros FC, Juan L et al. Global epidemiology of use of and disparities in caesarean sections. Lancet. 2018;392(10155):1341-8.

5. Betran AP, Torloni MR, Zhang JJ, Gülmezoglu AM; WHO Working Group on Caesarean Section. WHO 
Statement on Caesarean Section Rates. BJOG. 2016;123(5):667-70.

6. Gibbons L, Belizán JM, Lauer JA, Betrán AP, Merialdi M, Althabe F. The global numbers and costs of additionally needed and unnecessary caesarean sections performed per year: overuse as a barrier to universal coverage. World health report. 2010;30:1-31.

7. Saha L, Chowdhury SB. Study on primary Caesarean section. Mymensingh Med J. 2011;20(2):292-7.

8. Betrán AP, Ye J, Moller A-B, Zhang J, Gülmezoglu AM, Torloni MR. The Increasing Trend in Caesarean Section Rates: Global, Regional and National Estimates: 1990-2014. PLoS One. 2016;11(2):e0148343.

9. Daniel $\mathrm{CN}$, Singh S. Caesarean delivery: An experience from a tertiary institution in north western Nigeria. Niger J Clin Pract. 2016;19(1):18-24.

10. World Health Organization. Monitoring Emergency Obstetris care. A handbook. Geneva Switzerland: World Health Organization; 2009;79-99. Available at: https://www.who.int/reproductivehealth/publications/monitoring/9789241547734/en/. Accessed on 17 March 2021.

11. Osonwa OK, Eko JE, Ekeng PE. Trends in caesarean section at Calabar General Hospital, Cross River State, Nigeria. Eur J Biol Med Sci Res. 2016;4(1):15.

12. Isah AD, Adewole, Zaman. A five-year survey of Caesarean delivery at a Nigerian tertiary hospital. Trop J Obstet Gynaecol. 2018;35:14-7.
13. Batieha AM, Al-Daradkah SA, Khader YS, Basha A, Sabet $\mathrm{F}$ et al. Caesarean Section: Incidence, Causes, Associated Factors and Outcomes: A National Prospective Study from Jordan. Gynecol Obstet Case Rep. 2017;3(3):55.

14. John C, Alegbeleye J. Caesarean Delivery at a Teaching Hospital, South-South Nigeria: A FiveYear Review. Int J Trop Dis Heal. 2017;21(2):1-6.

15. Ugwu EO, Obioha KC, Okezie OA, Ugwu AO. A five-year survey of caesarean delivery at a Nigerian tertiary hospital. Ann Med Health Sci Res. 2011;1(1):77-83.

16. Panti A, Karima T, Nwobodo E, Yakubu A, Airede L, Egondu S. Caesarean morbidity and mortality in a tertiary health institution in Sokoto, North-West Nigeria. Orient Journal of Medicine. 1989;24:7-12.

17. Chama CM, El-Nafaty AU, Idrisa A. Caesarean morbidity and mortality at Maiduguri, Nigeria. J Obstet Gynaecol. 2000;20:45-8.

18. Okonta PI, Otoide VO, Okogbenin A. Caesarean section at the University of Benin Teaching Hospital revisited. Trop J Obstet Gynaecol. 2003;20:63-6.

Cite this article as: Ottun AT, Okoye $\mathrm{CH}$, Adewunmi AA, Jinadu FO, Olumodeji AM. Pattern of primary caesarean deliveries in a Nigerian tertiary hospital. Int J Reprod Contracept Obstet Gynecol 2021;10:2164-68. 